\title{
STRATEGI GURU BK DALAM MENUMBUHKAN SIKAP TOLERANSI PESERTA DIDIK
}

\author{
Arina Fithriyana \\ IAIN Kudus \\ Email: arinaf@iainkudus.ac.id
}

\begin{abstract}
Abstrak
Tujuan penelitian ini adalah untuk mengetahui gambaran umum sikap intoleransi peserta didik dan strategi yang dilakukan guru bimbingan dan konseling dalam menumbuhkan sikap toleransi peserta didik. Jenis penelitian ini menggunakan penelitian deskriptif kualitatif. Data penelitian didapat dari hasil observasi, wawancara, dan studi dokumentasi. Data tersebut kemudian dianalisis melalui tiga tahapan yaitu reduksi data, penyajian data, dan penarikan kesimpulan. Hasil analisis disajikan berupa data deskripsi mengenai fokus yang diteliti. Berdasarkan hasil penelitian diketahui bahwa mayoritas peserta didik di SMP N 18 Semarang telah memiliki sikap toleransi tetapi masih ada peserta didik yang menunjukkan sikap intoleransi. Sikap intoleransi yang ditunjukkan oleh peserta didik berdasarkan hasil observasi dan wawancara adalah peserta didik yang merasa tidak berkewajiban untuk menghormati agama orang lain, tidak suka bergaul dengan orang yang kedudukannya lebih rendah ataupun lebih tinggi, mengolok-olok teman yang berbeda dengan dirinya, dan adanya pengelompokan peserta didik sehingga ada peserta didik yang merasa dikucilkan. Dalam menyikapi fenomena tersebut, guru BK di SMP N 18 Semarang melakukan layanan bimbingan kelompok dengan memadukan teknik diskusi kelompok dengan teknik symbolic modeling. Layanan bimbingan kelompok tersebut menjadi strategi guru BK dalam menumbuhkan sikap toleransi peserta didik kelas VIII SMP N 18 Semarang. Layanan bimbingan kelompok dengan teknik diskusi kelompok yang dipadukan dengan teknik symbolic modeling ini diharapkan dapat digunakan oleh guru BK tidak hanya di tempat penelitian tetapi dapat digeneralisasikan di sekolah-sekolah yang lain. Selain itu, masih terbuka peluang bagi peneliti selanjutnya untuk meneliti strategi yang dapat dilakukan oleh guru BK melalui berbagai layanan bimbingan dan konseling.
\end{abstract}

Keywords: strategi guru BK, sikap toleransi, symbolic modeling

\section{PENDAHULUAN}

Negara Indonesia merupakan negara yang majemuk. Tidak hanya memiliki perbedaan suku, budaya, bahasa, tetapi juga perbedaan agama. Berdasarkan pada data yang diambil oleh Badan Pusat Statistik (BPS) Indonesia pada tahun 2010, terdapat sekitar 1.340 suku bangsa yang tersebar di seluruh pulau di Indonesia. Jumlah ini akan terus bertambah seiring dengan perkembangannya. Indonesia juga memiliki 652 bahasa daerah yang berbeda berdasarkan pada data yang diambil oleh Badan Pengembangan dan Pembinaan Bahasa kementerian Pendidikan dan Kebudayaan. Selain itu, Indonesia juga memiliki beragam agama. Agama yang diakui oleh pemerintah Indonesia pada saat ini ada 6 agama yaitu Islam, Kristen, Katolik, Hindu, Budha, dan khonghucu. Berbagai perbedaan baik budaya, bahasa, dan agama inilah yang menjadikan Indonesia negara yang majemuk.

Sebagai bangsa yang hidup dalam negara yang majemuk, bangsa Indonesia diharapkan dapat saling bertoleransi satu sama lain. Sikap yang menunjukkan toleransi ini perlu ditumbuhkan sejak dini di bangku sekolah. Peserta didik perlu untuk diajarkan bagaimana caranya bertoleransi dengan sesamanya, dan berteman dengan 
saudara-saudaranya yang sebangsa dan setanah air meskipun memiliki suku, bahasa, dan agama yang berbeda.

Toleransi pada kenyataannya merupakan keanekaragaman yang berkaitan dengan agama budaya dan tradisi (Cahyono et al., 2018). Semakin besar keanekaragaman suatu bangsa maka akan semakin besar juga sifat toleransinya. Dalam dunia pendidikan, peserta didik yang berasal dari berbagai suku bangsa dan agama saling berinteraksi satu sama lain. Apabila tidak ada toleransi diantara peserta didik, maka akan timbul berbagai permasalahan yang dialami oleh peserta didik. Oleh karena itu, guru perlu untuk menanamkan sikap bertoleransi dalam diri peserta didik. Sikap toleransi ini sangat penting untuk ditanamkan sejak dini pada peserta didik (Jumiatmoko, 2018).

Berbagai kasus yang berkaitan dengan sikap toleransi saat ini banyak yang behubungan dengan perbedaan agama dan keyakinan di dalam suatu komunitas. Berdasarkan data dari Setara Institute pada periode bulan Januari hingga November 2013 terjadi 243 tindakan pelanggaran kebebasan beragama dan berkeyakinan (Erdianto, 2016). Contoh kasus intoleransi di masyarakat misalnya penolakan pembangunan masjid di Kota Manado pada tahun 2016. Selain itu, adanya peraturan yang condong kepada satu agama tertentu dan tidak memerhatikan agama yang lain.

Sikap intoleransi juga menjadi permasalah tersendiri dalam dunia pendidikan. Sikap intoleransi tidak hanya ditunjukkan oleh peserta didik saja, tetapi juga guru sebagai pendidik. Berdasarkan hasil survei yang dilakukan oleh Setara Institute terhadap 760 responden siswa SMA di Jakarta dan Bandung yang dilakukan pada tahun 2016 mengenai tingkat toleransi pada siswa didapatkan hasil ada $61,6 \%$ peserta didik yang telah memiliki sikap toleransi, $35,7 \%$ peserta didik memiliki sikap intoleransi pasif atau sebatas pikiran, 2,4\% peserta didik menunjukkan sikap intoleransi aktif dan sampai pada tahap tidak suka, dan $0,3 \%$ menunjukkan gejala berpotensi menjadi teroris (Pratiwi, 2016). Sebagian besar responden pada survei ini beragama Islam dengan lebih banyak peserta didik laki-laki yang menjadi responden dibanding perempuan. Meskipun dalam survei tersebut terlihat bahwa sebagian besar peserta didik telah menunjukkan sikap toleransi, tetapi jika peserta didik yang menunjukkan sikap intoleransi dibiarkan dikhawatirkan akan menimbulkan permasalahan baik di lingkungan sekolah maupun di masyarakat nantinya.

Sikap intoleransi yang banyak muncul menurut Dahnil Anzar Simanjutak (Ketua Pimpinan Pusat Pemuda Muhammadiyah) disebabkan oleh rendahnya literasi sejarah. Rendahnya pengetahuan sejarah dinilai melemahkan sikap toleransi peserta didik. Padahal dalam literasi sejarah, banyak tokoh-tokoh yang memiliki sikap toleransi dan dapat dijadikan contoh bagi peserta didik (Erdianto, 2016). Berbagai tokoh ini dapat menjadi model bagi peserta didik. Hal ini sejalan dengan penelitian yang dilakukan oleh Astiasari dkk dalam penelitiannya mengenai pengaruh layanan bimbingan kelompok dengan teknik modeling terhadap peningkatan karakter toleransi. Hasil dari penelitian tersebut menunjukkan bahwa layanan bimbingan kelompok dengan teknik modeling dapat digunakan untuk mengembangkan karakter toleransi peserta didik (Astiasari et al., 2015). Berdasarkan penelitian tersebut, dapat diketahui bahwa layanan bimbingan kelompok dengan teknik modeling dapat meningkatkan karakter toleransi siswa. Pada penelitian ini, strategi yang dilakukan guru BK di SMP 18 Semarang dalam menumbuhkan sikap toleransi peserta didik melalui layanan bimbingan kelompok lebih dikhususkan dengan menggunakan teknik symbolic modeling.

Penelitian lain mengenai toleransi dilakukan oleh Maharani dkk. Maharani dkk meneliti mengenai penggunaan layanan bimbingan kelompok untuk meningkatkan toleransi dalam interaksi sosial siswa. Penelitian ini bertujuan untuk mengetahui peningkatan toleransi dalam interaksi sosial melalui layanan bimbingan kelompok. 
Hasilnya adalah terdapat peningkatan toleransi dalam interaksi sosial siswa setelah melakukan bimbingan kelompok (Maharani et al., 2020). Pada penelitian ini, layanan bimbingan kelompok yang dilakukan menggunakan teknik diskusi dengan tema gaya belajar. Adapun pada penelitian ini, guru BK menggunakan layanan bimbingan kelompok dengan teknik diskusi kelompok dengan tema menumbuhkan sikap toleransi. Selain itu, guru BK juga mencoba memadukan penggunaan teknik diskusi kelompok dengan teknik symbolic modeling.

Salah satu strategi layanan bimbingan dan konseling untuk menanamkan sikap toleransi siswa yang dilakukan oleh Caraka dkk dalam artikelnya yaitu dengan memberikan layanan konseling lintas budaya. Konseling lintas budaya dilakukan dengan mengunakan strategi cooperative learning yang dipadukan dengan strategi pencapaian konsep dan analisis nilai. Strategi tersebut dilakukan dengan cara siswa mempraktekkan langsung melalui seni-seni tradisional seperti permainan tradisional, tari-tarian, dan lain-lain. Strategi layanan bimbingan dan konseling dengan mengunakan konseling lintas budaya yang ditawarkan oleh Caraka dkk ini bertujuan untuk menanamkan sikap toleransi pada siswa Sekolah Dasar (Bhakti et al., 2019). Sementara itu, penelitian ini dilakukan untuk mencari strategi yang tepat untuk menumbuhkan sikap toleransi pada peserta didik tingkat Sekolah Menengah Pertama khususnya di SMP N 18 Semarang.

Peserta didik yang terdaftar di SMP N 18 Semarang berasal dari berbagai daerah, suku, dan agama. Kondisi peserta didik yang multikultural ini menuntut semua guru terutama guru bimbingan dan konseling untuk membimbing dan mengarahkan peserta didiknya saling bertoleransi satu sama lain. Oleh karena itu, tujuan penelitian ini adalah untuk mengetahui gambaran umum sikap intoleransi peserta didik dan strategi yang dilakukan guru bimbingan dan konseling dalam menumbuhkan sikap toleransi peserta didik.

\section{METODE}

Penelitian ini menggunakan penelitian analisis deskriptif kualitatif. Penelitian ini berlokasi di SMP N 18 Semarang dengan subyek penelitian adalah guru BK dan peserta didik kelas VIII SMP N 18 Semarang. Peserta didik yang menjadi subjek penelitian dipilih dengan menggunakan teknik purposive sampling sesuai dengan tujuan penelitian. Fokus penelitian ini yaitu strategi guru BK dan sikap toleransi peserta didik. Sumber data penelitian terdiri dari data primer dan sekunder. Data primer diperoleh dari guru BK dan peserta didik kelas VIII SMP N 18 Semarang. Pengumpulan data primer ini didasarkan pada hasil observasi, wawancara, dan studi dokumentasi. Adapun data sekunder dikumpulkan dari studi kepustakaan. Data atau informasi yang didapat kemudian dikumpulkan, dan dianalisis. Analisis data dilakukan melalui tiga tahapan yaitu reduksi data (data reduction), penyajian data (data display), dan penarikan kesimpulan (conclusion drawing). Hasil analisis berupa gambaran atau deskripsi mengenai fokus yang diteliti.

\section{HASIL DAN PEMBAHASAN Sikap Intoleransi}

Sikap menurut Muawanah merupakan perasaan, pikiran, dan kecenderungan seseorang yang bersifat permanen terhadap aspek-aspek tertentu dalam lingkungannya (Muawanah, 2018, p. 61). Adapun sikap (attitude) menurut Sarwono yaitu suatu istilah yang menggambarkan rasa senang, tidak senang, atau biasa-biasa saja (netral) oleh seseorang terhadap sesuatu (Sarwono, 2012, p. 201). Sikap yang terdapat pada diri individu akan memberi warna atau corak tingkah laku individu yang bersangkutan. Dalam hal ini, sikap bukan dimaknai sebagai tingkah laku melainkan kecenderungan seseorang untuk bertingkah laku dengan cara-cara tertentu terhadap suatu objek. 
Berdasarkan pengertian tersebut, dapat diketahui bahwa sikap bersifat subjektif. Sikap didasarkan pada perasaan individu terhadap objek yang dihadapinya. Sikap berhubungan dengan perasaan, persepsi, motif, kognisi, dan emosi yang ada dalam diri individu. Faktor penyebab sikap seseorang adalah suatu objek atau stimulus yang menjadi target sikap. Oleh karena itu, sikap yang ditunjukkan oleh individu terhadap satu objek yang sama dapat berbeda satu sama lain.

Sikap menurut Sarwono dapat dibagi menjadi tiga domain yaitu Affect, Behaviour, dan Cognition (Sarwono, 2012, p. 201). Affect berkaitan dengan perasaan yang timbul dalam diri individu terhadap suatu objek seperti senang dan tidak senang. Behaviour berkaitan dengan tingkah laku yang mengikuti perasaan yang timbul seperti mendekat atau menghindar. Cognition berupa penilain terhadap objek sikap meliputi bagus dan tidak bagus. Objek sikap dapat berupa benda, kejadian, situasi, orang atau sekelompok orang. Apabila perasaan yang timbul dalam diri individu berupa perasaan senang maka dapat dikatakan bahwa individu tersebut menunjukkan sikap positif. Begitu juga sebalinya, jika perasaan yang timbul berupa perasaan yang negatif, maka individu tersebut memiliki sikap yang negatif terhadap objek sikap.

Toleransi berasal dari bahasa latin,"tolerantia" yang memunyai arti kelonggaran, keringanan, kelembutan hati dan kesabaran. Menurut KBBI, toleransi berasal dari kata "toleran" yang berarti sifat atau bersikap menenggang, (menghargai, membiarkan, membolehkan), pendirian (pendapat, pendangan, kepercayaan, kebiasaan, dan sebagainya) yang berbeda atau bertentangan dengan pendiriannya (Depdiknas, 2008, pp. 1477-1478). Menurut Umar Hasyim, toleransi adalah pemberian kebebasan kepada setiap manusia untuk menjalankan kepercayaan dan keyakinan untuk mengatur hidupnya selama tidak bertentangan dengan kedamaian atau ketertiban masyarakat (Hasyim, 1979, p. 22).

Menurut UNESCO, toleransi adalah perbuatan saling menghargai dan menghormati di dalam keragaman budaya, serta kebebasan berekspresi dan perilaku manusia. Toleransi harus didasari dengan sebuah pengetahuan yang luas, keterbukaan sikap, kebebasan berpikir, dan beragama. UNESCO menambahkan bahwa toleransi itu berarti sikap positif untuk menghargai hak orang lain dalam menggunakan kebebasan haknya sebagai manusia (Muawanah, 2018).

Sikap toleransi yaitu perasaan, pikiran, dan tingkah laku individu yang bersifat menenggang, menghargai, dan membolehkan pendirian, pendapat, pandangan, kepercayaan, keyakinan, dan sebagainya yang berbeda atau bertentangan dengan pendiriannya. Dengan kata lain, sikap intoleransi merupakan perasaan, pikiran, dan tingkah laku individu dimana ia tidak menerima, menghargai, dan menghormati pendirian, pendapat, kepercayaan, pendapat, dan sebagainya

Berdasarkan hasil wawancara dengan guru bimbingan dan konseling di SMP N 18 Semarang diketahui bahwa peserta didik yang tercatat di kelas VIII keseluruhannya berjumlah 286 peserta didik. Peserta didik meskipun sebagian besar berasal dari Kota Semarang tetapi ada juga berasal dari berbagai kota di Indonesia seperti Magelang, Kendal, Pati, Sragen, Boyolali, Bontang, Pamekasan, Jakarta, Palembang, dan lain sebagainya. Peserta didik di SMP N 18 Semarang mayoritas beragama Islam tetapi ada juga peserta didik yang memiliki agama Kristen yaitu berjumlah 9 orang dan Katolik sebanyak 5 orang. Selain itu, peserta didik juga berasal dari berbagai latar belakang keluarga dan ekonomi yang beragam. Berdasarkan keterangan tersebut, tampaklah bahwa keberagaman peserta didik yang bersekolah di SMP N 18 Semarang.

Banyak keberagaman yang berkaitan dengan kehidupan dan aktivitas peserta didik di sekolah (Endang, 2009, p. 89). Peserta didik datang ke sekolah dengan membawa latar belakang budaya kebiasaan-kebiasaan yang dipengaruhi oleh lingkungan keluarga, masyarakat dimana ia hidup, dan nilai-nilai agama yang dianutnya. Keberagaman ini tercermin dalam bentuk sikap dan tingkah laku peserta 
didik di sekolah. Oleh karena itu, nilai-nilai toleransi perlu ditumbuhkan dalam diri peserta didik supaya mereka dapat saling menerima, menghargai, dan menghormati perbedaan yang ada satu sama lain. Sikap toleransi diantara peserta didik dapat dimaknai sebagai penerimaan, penghargaan, dan penghormatan terhadap keragaman budaya, kebiasaan, keyakinan, dan perbedaan pendapat yang ada di lingkungan sekolah.

Lebih lanjut, berdasarkan keterangan yang didapat dari guru Bimbingan dan Konseling yang didasarkan pada data yang didapatkan diketahui bahwa mayoritas peserta didik di SMP N 18 Semarang telah menunjukkan sikap toleransi kepada sesamanya. Akan tetapi masih ada sebagian kecil peserta didik yang merasa tidak berkewajiban untuk menghormati agama orang lain, sering bertentangan pendapat dengan orang lain, sulit menerima kekalahan, tidak suka bergaul dengan orang yang kedudukannya lebih rendah ataupun lebih tinggi, dan bersikap kaku serta tidak toleransi kepada orang lain. Apabila kondisi yang ada dalam peserta didik ini dibiarkan, ditakutkan akan menyebabkan permasalah baru baik ketika ia berada di sekolah maupun di lingkungan masyarakat saat ini ataupun di masa depan.

Selain itu, berdasarkan hasil pengamatan yang dilakukan oleh peneliti diketahui bahwa peserta didik kelas VIII SMP N 18 Semarang masih ada yang menunjukkan sikap intoleransi. Misalnya, peserta didik memanggil temannya dengan menggunakan nama orang tuanya atau nama panggilan lain yang tidak sesuai. Ketika pelaksanaan bimbingan kelompok berlangsung, ada peserta didik yang tidak memerhatikan guru dan berbicara sendiri dengan temannya. Ada juga peserta didik yang mengolok-olok temannya yang berjenis kelamin laki-laki tetapi bersikap seperti perempuan. Selain itu, terjadi pengelompokan peserta didik di dalam kelas yang terdiri dari peserta didik yang berbeda agama bahkan ada yang dikucilkan dalam kelas tersebut. Ada juga fenomena peserta didik yang menganggap bahwa mengejek temannya adalah suatu hal yang biasa. Apabila sikap intoleransi peserta didik ini dibiarkan berlanjut, dikhawatirkan akan terjadi perpecahan dan konflik diantara peserta didik.

Pembentukan sikap intoleransi peserta didik ini terjadi melalui kontak sosial antara individu satu dengan individu-individu lain di lingkungan sekitarnya secara terus menerus. Menurut Sarwono, faktor yang memengaruhi terbentuknya sikap dapat dibagi menjadi dua, yaitu sebagai berikut (Sarwono, 2012, p. 206).

1. Faktor internal, adalah faktor yang terdapat dalam diri individu yang bersangkutan. Faktor ini ditentukan oleh motif, perbedaan minat, dan kecenderungan-kecenderungan yang ada dalam diri individu.

2. Faktor eksternal, adalah faktor yang berasal dari luar diri individu. Faktor ini antara lain dipengaruhi oleh sifat objek itu sendiri, kewibawaan yang ada dalam diri individu, sifat orang lain atau sekelompok orang yang mendukung sikap tersebut, media komunikasi yang menyampaikan berita mengenai sikap tersebut, dan situasi yang terjadi pada saat sikap tersebut dibentuk.

Adapun faktor-faktor yang memengaruhi toleransi adalah sebagai berikut (Hanim, 2017).

1. Tahapan perkembangan individu yang berpengaruh terhadap cara seseorang memahami, memaknai, dan menghadapi perbedaan yang ada.

2. Jenis kepribadian individu dimana seseorang dengan jenis kepribadian tertentu cenderung bersikap intoleransi.

3. Hierarki kebutuhan individu berkaitan dengan kecenderungan seseorang bersikap sesuai dengan tingkat kebutuhannya.

4. Pengalaman yang dialami oleh individu berkaitan dengan cara seseorang memerlakukan dan diperlakukan di lingkungan sekitarnya sehingga menjadi suatu kebiasaan. 
5. Pemahaman individu yang didapat melalui pengajaran mengenai sikap toleransi baik oleh orangtua maupun guru di sekolah.

6. Peniruan individu terhadap tingkah laku yang dilakukan oleh orang-orang disekitarnya seperti orangtua, saudara, teman, dan sebagainya.

Adanya sikap toleransi antar sesama dalam suatu negara dapat mempererat persatuan dan kesatuan bangsa. Sebaliknya, sikap intoleransi yang tumbuh dapat menyebabkan perpecahan dan mengikis nilai nasionalisme kebangsaan. Salah satu penyebab terkikisnya nilai nasionalisme bangsa yaitu berkembangnya paham keagamaan yang radikal (Zafi, 2019). Paham keagamaan yang radikal juga menjadi penyebab munculnya sikap intoleransi beragama. Oleh karena itu, guru BK perlu menumbuhkan sikap toleransi dalam diri peserta didik sebagai generasi penerus bangsa.

\section{Strategi Guru Bimbingan dan Konseling dalam Menumbuhkan Sikap Toleransi}

Guru bimbingan dan konseling berperan dalam menjaga kondisi peserta didik yang sudah baik agar tetap baik dan membimbing peserta didik yang belum baik supaya menjadi baik. Dalam hal ini, guru bimbingan dan konseling membuat suatu strategi dalam mengatasi hal tersebut. Salah satu strategi yang dilakukan oleh guru bimbingan dan konseling adalah dengan memberikan layanan bimbingan kelompok. Melalui kegiatan layanan bimbingan kelompok, peserta didik belajar untuk menghargai dan menghormati pendapat dan keyakinan peserta didik lainnya yang menjadi anggota kelompok.

Bimbingan kelompok menurut Prayitno merupakan suatu kegiatan yang dilakukan oleh sekelompok individu dengan memanfaatkan dinamika kelompok (Satriah, 2017, p. 4). Pengertian tersebut mengandung arti bahwa semua anggota kelompok dalam bimbingan kelompok bebas untuk saling berinteraksi, mengeluarkan pendapat, menanggapi, memberi saran, dan lain sebagainya. Adapun kelompok menurut Rasimin dan Hamdi menjadi sarana atau media penghubung bagi para anggota kelompok yang mengikuti kegiatan layanan bimbingan kelompok serta memungkinkan para anggota kelompok berperan serta aktif dalam berbagi pengalaman, pengembangan wawasan, sikap, keterampilan, pencegahan timbulnya masalah, dan pengembangan pribadi anggota kelompok (Rasimin \& Hamdi, 2018, p. 4).

Bimbingan kelompok dipilih oleh guru BK di SMP N 18 Semarang karena memiliki berbagai manfaat. Manfaat dari layanan bimbingan kelompok menurut Hartinah \& Sitti adalah sebagai berikut (Hanim, 2017).

1. Peserta didik mampu menganalisis sikap dan tingkah laku yang dimilikinya serta lebih mengenal dirinya.

2. Sikap dan sifat peserta didik yang terbentu menjadi lebih baik dan positif dalam interaksi sosial dengan peserta didik lainnya.

3. Peserta didik menjadi lebih menghargai pendapat orang lain, bertanggung jawab, dan memiliki sikap toleransi.

4. Dapat mengurangi sikap agresif, pemarah, dan penakut yang dimiliki oleh peserta didik.

5. Dapat mengurangi ketegangan emosi, frustrasi, dan konflik dalam diri peserta didik.

6. Dapat mendorong peserta didik memiliki sikap saling memiliki, suka menolog, dan berhati-hati dalam bertindak.

Ada berbagai macam teknik dalam bimbingan kelompok yang dapat digunakan untuk menumbuhkan sikap toleransi peserta didik. Salah satu teknik bimbingan kelompok yang dilakukan oleh guru bimbingan dan konseling di SMP N 18 Semarang yaitu dengan menggunakan teknik diskusi kelompok dan menceritakan berbagai kisah tokoh-tokoh sebagai model symbolic bagi peserta didik dalam bersikap toleransi kepada 
orang lain. Teknik diskusi kelompok dipilih karena berbagai kelebihan yang dimiliki oleh teknik tersebut. Menurut Romlah kelebihan dari teknik diskusi kelompok antara lain sebagai berikut (Romlah, 2006, p. 90).

1. Membuat anggota kelompok lebih aktif karena setiap anggota kelompok diberikan kesempatan untuk berbicara dan mengeluarkan pendapatnya secara setara.

2. Anggota kelompok dapat saling bertukar pengalaman, pikiran, perasaan, dan nilainilai yang dimilikinya kepada anggota kelompok lainnya.

3. Anggota kelompok dapat belajar mendengarkan perkataan atau pendapat anggota kelompok yang lain secara baik.

4. Anggota kelompok dapat meningkatkan pengertian terhadap dirinya sendiri dan orang lain yang berada dalam kelompok.

Menurut beberapa ahli tujuan penggunaan teknik diskusi kelompok yaitu untuk mengembangkan keterampilan-keterampilan kepemimpinan, merangkum pendapatpendapat kelompok, mencapai suatu konsesus, berlatih menjadi pendengar yang aktif, mengatasi perbedaan-perbedaan yang ada secara tepat, mengembangkan keterampilan untuk memparafase, mengembangkan berbagai keterampilan untuk belajar mandiri, dan mengembangkan keterampilan dalam menganalisis, mensistesis, dan menilai (Romlah, 2006, p. 89). Bimbingan kelompok dengan teknik diskusi merupakan suatu layanan bantuan yang diselenggarakan oleh guru bimbingan dan konseling di sekolah kepada peserta didik dengan tujuan memeroleh penyesuaian diri dan pemahaman mengenai toleransi dalam interaksi sosial (Maharani et al., 2020).

Sebelum memulai layanan bimbingan kelompok ada beberapa hal yang dipersiapkan oleh guru BK di SMP N 18 Semarang yaitu persiapan materi dan pemilihan anggota kelompok. Persiapan materi dilakukan dengan mencari berbagai referensi video atau audio kisah-kisah berbagai tokoh yang menunjukkan sikap toleransi terhadap sesama (Sufanti et al., 2015). Adapun anggota kelompok yang dipilih untuk mengikuti layanan bimbingan kelompok terdiri dari 8-10 orang peserta didik.

Pemilihan anggota kelompok dalam kegiatan bimbingan kelompok untuk menumbuhkan sikap toleransi peserta didik dilakukan dengan prinsip heterogenitas kelompok. Anggota kelompok yang dipilih merupakan peserta didik yang berbeda agama, berbeda latar belakang ekonomi keluarga, berasal dari daerah yang berbeda, dan berbeda jenis kelamin. Selain itu, anggota kelompok juga terdiri dari peserta didik yang sudah menunjukkan sikap toleransi dan yang masih bersikap intoleransi kepada orang lain. Hal ini dilakukan dengan harapan bahwa anggota kelompok yang heterogen akan menjadi sumber yang kaya untuk mencapai tujuan layanan bimbingan kelompok (Prayitno, 2017, p. 139). Selain itu, kondisi anggota kelompok yang heterogen diharapkan dapat memperkaya dinamika kelompok sehingga terjadi proses saling memberi dan menerima, saling mengasah, saling merangsang, dan saling merespon terhadap topik yang dibahas dalam layanan bimbingan kelompok (Prayitno, 2017, p. 149). Dalam hal ini, peserta didik yang telah menunjukkan sikap toleransi kepada orang lain dapat memberikan pendapatnya, menjadi contoh, dan mendorong anggota kelompok lainnya yang masih bersikap intoleransi untuk bersikap toleransi kepada orang lain.

Layanan bimbingan kelompok dilaksanakan melalui 5 tahapan, yaitu tahap pembentukan, peralihan, kegiatan, penyimpulan, dan pengakhiran (Prayitno, 2017, pp. 149-150). Pada tahap pembentukan, guru BK di SMP N 18 Semarang membangun hubungan baik dengan anggota kelompok, menjelaskan pengertian dan tujuan bimbingan kelompok, serta tata cara pelaksanaan bimbingan kelompok. Selanjutnya, guru BK juga menjelaskan mengenai asas-asas yang terdapat dalam bimbingan kelompok. Pelaksanaan bimbingan kelompok tetap mengikuti asas-asas bimbingan dan konseling. Salah satu asas yang ditekankan dalam kegiatan ini adalah asas kenormatifan. Tujuannya adalah anggota kelompok dapat belajar untuk saling 
menghargai dan menghormati pendapat yang disampaikan oleh anggota kelompok. Anggota kelompok belajar untuk mengungkapkan pendapatnya dengan menggunakan bahasa yang sopan dan santun sehingga tidak menyinggung perasaan anggota kelompok yang lain, tidak menyela anggota kelompok yang sedang mengungkapkan pendapatnya, dan menanggapi pendapat anggota kelompok yang lain secara baik (Puluhulawa et al., 2017). Guru BK juga memberikan ice breaking dengan tujuan untuk lebih mengeratkan hubungan diantara anggota kelompok.

Pada tahap peralihan, guru BK menjelaskan kembali mengenai kegiatan bimbingan kelompok secara singkat dan menyiapkan anggota kelompok untuk mengikuti tahap kegiatan. Pada tahap kegiatan, guru BK sebagai pemimpin kelompok mengarahkan jalannya diskusi kelompok yang dilakukan oleh anggota kelompok. Topik yang dibahas dalam kegiatan bimbingan kelompok dengan teknik diskusi kelompok ini adalah mengenai sikap toleransi. Pemimpin kelompok mendorong anggota kelompok untuk mendiskusikan mengenai makna sikap toleransi, manfaat bersikap toleransi, jenis-jenis toleransi, dan ciri-ciri sikap toleransi. Setelah anggota kelompok mendiskusikan mengenai topik yang dibahas secara tuntas, pemimpin kelompok memberikan contoh-contoh sikap toleransi dengan memutarkan video mengenai kisah berbagai tokoh. Kisah dari berbagai tokoh tersebut dijadikan sebagai model symbolic bagi anggota kelompok.

Kisah berbagai tokoh yang mencerminkan sikap toleransi antara lain sebagai berikut.

1. Nabi Muhammad SAW

Kisah yang dapat diteladani dari Nabi Muhammad SAW antara lain Beliau berdiri saat ada rombongan orang Yahudi yang menghantarkan jenazah ketika sedang duduk bersama para sahabat. Contoh lain dari toleransi beragama yang diajarkan oleh Nabi Muhammad SAW yaitu melarang umat muslim menghancurkan rumah ibadah umat lain, harus bersikap adil terhadap sesama, menjaga hak orang lain meskipun berbeda agama, dan lain sebagainya.

2. Bunda Theresa

Bunda Theresa merupakan seorang biarawati agama Katolik. Beliau salah satu tokoh yang memerjuangkan kemanusiaan dan menentang ketidakadilan. Beliau mengabdikan hidunya untuk merawat anak-anak agama Hindu yang berada di India. Beliau tidak menghargai keyakinan yang dianut oleh anak-anak tersebut dan merawat mereka seperti anak sendiri.

3. Mahatma Gandhi

Mahatma Ghandi merupakan salah satu sosok tokoh dunia yang dikenal sebagai Bapak Anti-Kekerasan. Beliau sangat menjunjung tinggi sikap toleransi beragama dengan cara mempraktikkan sikap nonkekerasan dan toleransi terhadap semua agama yang berbeda. Selain itu, Beliau sangat membela hak asasi bagi semua umat manusia. Beliau juga bersahabat dengan orang yang berbeda agama dengannya. Kisah Beliau sangat inspiratif hingga PBB menetapkan tanggal 2 Oktober yang merupakan hari kelahiran Mahatma Gandhi sebagai Hari Tanpa Kekerasan Internasional.

4. Paus Fransiskus

Paus merupakan tokoh agama Katolik. Contoh toleransi yang dilakukan oleh Paus Fransiskus yaitu Beliau selalu melakukan ritual untuk membasuh dan mencium kaki umatnya setiap hari Paskah. Beliau juga pernah membasuh dan mencium kaki seorang muslim dan para narapidana pada saat perayaan Paskah. Beliau menganggap bahwa semua orang adalah sama di mata Tuhan.

Pada tahap penyimpulan, guru BK menilik ulang yang berbagai hal yang sudah dilakukan dan dicapai oleh kelompok. Pada tahap ini, pemimpin kelompok meminta 
anggota kelompok untuk mengemukakan hasil yang telah ia dapat selama mengikuti kegiatan bimbingan kelompok. Puncak dari tahap ini adalah pemimpin kelompok melakuka penilaian segera terhadap kegiatan bimbingan kelompok yang telah dilakukan. Penilaian segera dilakukan untuk mengetahui seberapa jauh pemahaman yang didapat oleh anggota kelompok, kesan terhadap kegiatan bimbingan kelompok yang telah dilakukan, dan tindakan anggota kelompok yang akan dilakukan setelah mengikuti kegiatan bimbingan kelompok. Selain itu, pemimpin kelompok juga meminta anggota kelompok untuk mengemukakan kesan, pesan, dan harapan terhadap pelaksanaan layanan bimbingan kelompok.

Pada tahap pengakhiran, guru BK menjelaskan kepada anggota kelompok bahwa kegiatan layanan bimbingan kelompok akan segera berakhir. Pemimpin kelompok juga menawarkan dan membahas mengenai perlunya diadakannya kegiatan lanjutan kepada anggota kelompok. Selanjutnya, pemimpin kelompok menyampaikan ucapan terima kasih kepada anggota kelompok yang telah mengikuti dan berperan aktif dalam kegiatan bimbingan kelompok. Tahap ini diakhiri dengan pemimpin kelompok memimpin do'a bersama dan membubarkan kelompok.

Berdasarkan penelitian yang telah dilakukan, strategi yang dilakukan oleh guru BK di SMP N 18 Semarang untuk menumbuhkan sikap toleransi peserta didiknya yaitu memberikan layanan bimbingan kelompok dengan menggunakan teknik diskusi kelompok dan dipadukan dengan teknik symbolic modeling. Symbolic modeling merupakan salah satu tipe dasar teknik modeling. Symbolic modeling digunakan untuk mengilustrasikan tingkah laku model melalui rekaman video atau audio (Erford, 2017, p. 340). Symbolic modeling memungkinkan guru BK untuk memberikan contoh atau demonstrasi tingkah laku yang lebih akurat. Selain itu, rekaman video atau audio dapat disimpan dan digunakan berulang-ulang kali.

\section{KESIMPULAN}

Kesimpulan yang dapat diambil dari penelitian ini adalah sebagai berikut. Pertama, sebagian besar peserta didik di SMP N 18 Semarang telah menunjukkan sikap toleransi. Akan tetapi masih ada peserta didik yang memiliki sikap intoleransi kepada peserta didik lainnya seperti masih ada yang merasa tidak berkewajiban untuk menghormati agama orang lain, mengolok-olok teman yang berbeda dengan dirinya, adanya pengelompokan peserta didik sehingga ada peserta didik yang merasa dikucilkan, tidak suka bergaul dengan orang yang kedudukannya lebih rendah ataupun lebih tinggi, dan bersikap kaku serta tidak toleransi kepada orang lain. Kedua, salah satu strategi guru BK dalam menumbuhkan sikap toleransi peserta didik yaitu dengan menggunakan layanan bimbingan kelompok yang memadukan teknik diskusi kelompok dengan symbolic modeling. Bagi peneliti selanjutnya masih terbuka peluang untuk mengeksplorasi pemberian layanan bimbingan kelompok untuk meningkatkan sikap toleransi peserta didik dengan menggunakan berbagai teknik.

\section{DAFTAR PUSTAKA}

Astiasari, R., Hanim, W., \& Badrudjaman, A. (2015). Peningkatan Karakter Toleransi (Studi Pre-Experiment Pada Siswa Kelas Vii Smp Labschool Jakarta). Jurnal Insight, 99-103. https://doi.org/https://doi.org/10.21009/INSIGHT.042.17

Bhakti, C. P., Aji, B. S., Kurniasih, C., \& Dahlan, U. A. (2019). Strategi layanan bimbingan dan konseling untuk penanaman sikap toleransi siswa sekolah dasar. 180-185. http://seminar.uad.ac.id/index.php/ppdn/article/view/1421 
Cahyono, T., Pribadi, H., \& Suriata, S. (2018). Penerapan Sosiodrama untuk Meningkatkan Toleransi. Jurnal Pengabdian Masyarakat Borneo, 2(1), 14. https://doi.org/10.35334/jpmb.v2i1.409

Depdiknas. (2008). Kamus besar Bahasa Indonesia Pusat Bahasa. PT Gramedia Pustaka.

Endang, B. (Untasn). (2009). Mengembangkan Sikap Toleransi Dan Kebersamaan Di Kalangan Siswa. Jurnal Visi Ilmu Pendidikan, 1(2), 89-105. https://doi.org/http://dx.doi.org/10.26418/jvip.v1i2.54

Erdianto, K. (2016). Yang Diwariskan Tokoh-tokoh Bangsa adalah Toleransi, Bukan Intoleransi.. Halaman all - Kompas.com. https://nasional.kompas.com/read/2016/06/20/07003701/yang.diwariskan.tokohtokoh.bangsa.adalah.toleransi.bukan.intoleransi.?page=all

Erford, B. T. (2017). 40 Teknik yang Harus Diketahui Setiap Konselor (H. P. S. dan S. M. Soetjipto (ed.); Kedua). Pustaka Pelajar.

Hanim, W. (2017). Pengaruh Teknik Role Playing dalam Bimbingan Kelompok Terhadap Toleransi pada Peserta Didik Kelas X SMK Negeri 26 Jakarta. Jurnal Insight, 6(2), 114-129. https://doi.org/https://doi.org/10.21009/INSIGHT.062.01

Hasyim, U. (1979). Toleransi dan Kemerdekaan Beragama dalam Islam Sebagai Dasar menuju Dialoq dan Kerukunan Antar Umat Beragama. Bina Ilmu.

Jumiatmoko, J. (2018). Peran Guru Dalam Pengembangan Sikap Toleransi Beragama Pada Anak Usia Dini. ThufuLA: Jurnal Inovasi Pendidikan Guru Raudhatul Athfal, 6(2), 199. https://doi.org/10.21043/thufula.v6i2.4033

Maharani, P., Widiastuti, R., \& Andriyanto, R. E. (2020). Penggunaan Layanan Bimbingan Kelompok untuk Meningkatkan Toleransi dalam Interaksi Sosial Pada Siswa The Application of Group Guidance Services to Increase Tolerance in Social Interaction among Students. 645. http://jurnal.fkip.unila.ac.id/index.php/ALIB/article/view/20415

Muawanah. (2018). Pentingnya Pendidikan untuk Tanamkan Sikap Toleran di Masyarakat. 5, 57-70. https://doi.org/10.31219/osf.io/vqgj4

Pratiwi, P. S. (2016). Aturan di Sekolah Hambat Sikap Toleransi pada Siswa. https://www.cnnindonesia.com/nasional/20160525015727-20-133226/aturan-disekolah-hambat-sikap-toleransi-pada-siswa

Prayitno. (2017). Konseling Profesional yang Berhasil: Layanan dan Kegiatan Pendukung: Rajawali Press.

Puluhulawa, M., Djibran, M. R., \& Pautina, M. R. (2017). Layanan Bimbingan Kelompok dan Pengaruhnya terhadap Self-Esteem Siswa. Proceeding Seminar Dan Lokakarya Nasional Bimbingan Dan Konseling 2017, 1, 301-310. http://journal2.um.ac.id/index.php/sembk/article/view/1410

Rasimin, \& Hamdi, M. (2018). Bimbingan dan Konseling Kelompok. Bumi Aksara. 
Romlah, T. (2006). Teori dan Praktek Bimbingan Kelompok. Penerbit Universitas Negeri Malang.

Sarwono, S. W. (2012). Pengantar Psikologi Umum. Rajawali Press.

Satriah, L. (2017). Bimbingan dan Konseling Kelompok (Seting Masyarakat). Fokusmedia.

Sufanti, M., Rahmawati, F. P., Fatimah, N., Pendahuluan, A., \& Merdeka, S. (2015). Kriteria biografi tokoh yang bermuatan toleransi kehidupan beragama. The 2nd University Research Coloquium, 1-10. https://jurnal.unimus.ac.id/index.php/psn12012010/article/view/1508

Zafi, A. A. (2019). Nilai Nasionalisme Kebangsaan Aktivis Rohis. BELAJEA: Jurnal Pendidikan Islam, 4(2), 165-184. https://doi.org/10.29240/belajea.v4i2.861 